\title{
Mice Lacking the TNF 55 kDa Receptor Fail to Sleep More After TNF $\alpha$ Treatment
}

\author{
Jidong Fang, Ying Wang, and James M. Krueger \\ Department of Physiology and Biophysics, University of Tennessee, Memphis, Tennessee 38163
}

Tumor necrosis factor (TNF) is a well characterized sleepregulatory substance. To study receptor mechanisms for the sleep-promoting effects of TNF, sleep patterns were determined in control and TNF $55 \mathrm{kDa}$ receptor knock-out (TNFR-KO) mice with a B6 $\times 129$ background after intraperitoneal injections of saline or murine TNF $\alpha$. The TNFR-KO mice had significantly less baseline sleep than the controls. TNF $\alpha$ dose-dependently increased non-rapid eye movement sleep (NREMS) in the controls but did not influence sleep in TNFR-KO mice. Although
TNFR-KO mice failed to respond to TNF $\alpha$, they had an increase in NREMS and a decrease in rapid eye movement sleep after interleukin- $1 \beta$ treatment. These results indicate that TNF $\alpha$ affects sleep via the $55 \mathrm{kDa}$ receptor and provide further evidence that TNF $\alpha$ is involved in physiological sleep regulation. Current results also extend the list of species to mice in which TNF $\alpha$ and interleukin- $1 \beta$ are somnogenic.

Key words: knock-out mice; REM sleep; slow-wave sleep; TNF receptor; EEG slow-wave activity; interleukin-1
Administration of exogenous tumor necrosis factor $\alpha$ (TNF $\alpha)$ (Shoham et al., 1987a; Kapás et al., 1992; Nistico et al., 1992) induces increases in non-rapid eye movement sleep (NREMS) in rabbits and rats. Conversely, inhibition of endogenous TNF using either anti-TNF $\alpha$ antibodies (Takahashi et al., 1995a), a TNFsoluble receptor, or a synthetic fragment of the TNF-soluble receptor (Takahashi et al., 1995b) inhibits spontaneous sleep. Inhibition of TNF also attenuates sleep rebound after sleep deprivation (Takahashi et al., 1996c), excess sleep induced by acute exposure to mild increases in ambient temperature (Takahashi et al., 1997), or sleep responses induced by bacterial cell wall products such as muramyl dipeptide (Takahashi et al., 1996b). TNF $\alpha$ mRNA (Hunt et al., 1992; Tchelingerian et al., 1994) and $\mathrm{TNF} \alpha$ immunoreactivity (Breder et al., 1993) are present in neurons in several areas of the normal rat brain including the hypothalamus, an area involved in NREMS regulation. $\mathrm{TNF} \alpha$ is also a product of astrocytes (Lieberman et al., 1989). Furthermore, hypothalamic levels of TNF $\alpha$ mRNA (Bredow et al., 1996) and TNF $\alpha$ (Floyd et al., 1996) in rats are greater during daylight hours, when rats sleep the most, than during the nighttime. TNF receptor mRNA is also expressed in normal brain (Hunt et al., 1992), and the soluble TNF receptor seems to be a normal constituent of CSF (Puccioni-Sohler et al., 1995). Circulating TNF may also be linked to sleep regulation. In humans, TNF plasma levels vary in phase with electroencephalographic (EEG) slow-wave activity (Darko et al., 1995). The ability of circulating monocytes to produce TNF is dependent on the sleep-wake cycle and increases during sleep deprivation (Yamasu et al., 1992; Hohagen et al., 1993; Uthgenannt et al.,

\footnotetext{
Received Feb. 5, 1997; revised April 28, 1997; accepted May 12, 1997.

This work was supported, in part, by National Institutes of Health Grants NS31453 and NS-25378 and the Office of Naval Research Grant N00014-90-J-1069. We thank Dr. Peggy Danneman for breeding the TNF-KO mice and Dr. W. Lesslauer for providing them. We also thank Mrs. Maria Swayze-Nations for her assistance in the preparation of this manuscript.

Correspondence should be addressed to Dr. James M. Krueger, Department of Physiology and Biophysics, The University of Tennessee, Memphis, 894 Union Avenue, Memphis, TN 38163.

Copyright (C) 1997 Society for Neuroscience $0270-6474 / 97 / 175949-07 \$ 05.00 / 0$
}

1994). Collectively, these data support the hypothesis that $\mathrm{TNF} \alpha$ is an important regulatory component in sleep regulation.

Two cell surface receptors for TNF [a $55 \mathrm{kDa}$ receptor (TNF55kDR) and a $75 \mathrm{kDa}$ receptor (TNF75kDR)] have been characterized (Hohmann et al., 1989; 1990; Schall et al., 1990). The extracellular domains of these receptors share significant amino acid homologies, although their intracellular domains do not. The actions mediated by these two receptors are distinct (Vilcek and Lee, 1991; for review, see Schutze et al., 1994). Which TNF receptor is involved in sleep regulation was heretofore unknown. Currently it is not possible to differentiate the two types of TNF receptors using pharmacological methods. However, the presence of mutant mice that lack TNF55kDR (Rothe et al., 1993) provided an opportunity to study the receptor mechanisms of TNF. These mutant mice still express TNF75kDR and develop normally with no apparent anomalies. It was, therefore, of interest to investigate sleep in these TNF55kDR knock-out (TNFR-KO) mice. We now report that the TNFR-KO mice sleep less than their strain controls and do not exhibit NREMS responses after the administration of exogenous $\mathrm{TNF} \alpha$, although they do retain the ability to express excess NREMS if given interleukin-1 $\beta$ (IL-1 $\beta$ ), another well characterized NREMSpromoting cytokine.

\section{MATERIALS AND METHODS}

Adult TNFR-KO mice $(n=14)$, which have a B6 $\times 129$ background (Rothe et al., 1993), and B6 $\times 129-\mathrm{F} 2$ control mice $(n=13)$ were used in the experiments. The TNFR-KO mice were provided by Dr. W. Lesslauer (F. Hoffmann-LaRoche, Ltd., Basel, Switzerland). Mice used in these experiments were $79.36 \pm 8.21 \mathrm{~d}$ old, weighing $28.12 \pm 1.52 \mathrm{gm}$. Control mice of the same age and weight were purchased from The Jackson Laboratory (Bar Harbor, ME). Mice were anesthetized with ketamine $(25 \mathrm{mg} / \mathrm{kg})$ and xylazine $(25 \mathrm{mg} / \mathrm{kg})$ and implanted with three EEG electrodes (Plastics One, Inc., Roanoke, VA) in the skull over the parietal cortex and three electromyogram (EMG) electrodes in the muscle of the dorsal neck, respectively. The electrodes with attached wires were fixed to the skull with dental cement. Ten days were allowed for recovery from surgery. Mice were housed at $30 \pm 1^{\circ} \mathrm{C}$ in separate recording cages in sound-attenuated environmental chambers with a 12 hr light/dark cycle (lights on at 5 A.M. and off at 5 P.M.). Each mouse received one $(1.0 \mu \mathrm{g} /$ mouse; $n=7$ for control mice and $n=7$ for 
TNFR-KO mice) or three doses $(0.3,1.0$, or $3.0 \mu \mathrm{g} /$ mouse; $n=6$ for control mice and $n=7$ for TNFR-KO mice) of the full-length recombinant murine $\mathrm{TNF} \alpha$ ( R \& D Systems, Inc., Minneapolis, MN) by intraperitoneal injections at dusk (5 P.M.). Each TNF $\alpha$ injection day was preceded by a saline injection day. The effects of TNF $\alpha$ on sleep were tested in an increasing dose order. There was a separation of $5 \mathrm{~d}$ between the previous TNF $\alpha$ injection and the next saline injection. The control and TNFR-KO mice received the same treatment according to the same schedule. In a separate experiment, the same TNFR-KO mice that received only $1 \mu \mathrm{g} \operatorname{TNF} \alpha(n=6)$ were also injected intraperitoneally with saline on the control day ( $3 \mathrm{~d}$ after the TNF $\alpha$ test) and IL-1 $\beta$ (R \& D Systems, Inc.) $(0.4 \mu \mathrm{g} /$ mouse $)$ on the experimental day.

In all experiments, EEG and EMG were recorded for $24 \mathrm{hr}$ after each injection. Sleep data were collected with a Grass Instruments (Quincy, MA) polygraph. The EEG signals were amplified with a 7P5 wide-band EEG preamplifier and a 7P-DA-G DC driver amplifier. The one-half cutoff for low and high frequencies was set at 0.5 and $35.0 \mathrm{~Hz}$, respectively. The EMG signals were amplified with a 7P511J amplifier with one-half cutoff for low and high frequencies set at 100 and $10,000 \mathrm{~Hz}$, respectively. The data collection was controlled by a 386 microcomputer. The J6 output from the DC drivers or 7P511J amplifiers was fed into a 12 bit PC30D analog-to-digital (AD) converter (Omega Engineering, Inc. Stamford, CT). The AD converter digitized the EEG and EMG signals at $128 \mathrm{~Hz}$. The digitized data were transferred to the computer and displayed graphically on the computer monitor. An on-line fast Fourier transformation (FFT) was performed on EEG data in every $2 \mathrm{sec}$ of data. The FFT analyses generated the power density values from 0.0 to $63.5 \mathrm{~Hz}$ at a $0.5 \mathrm{~Hz}$ resolution. The results of the FFT were averaged for every 10 sec. The sleep data and FFT results were saved to the hard disk for off-line analyses.

Data were scored to determine sleep parameters as described previously (Fang et al., 1996a). After data collection the EEG and EMG patterns and FFT data were displayed graphically on the screen of the computer monitor for sleep scoring. The behavioral states were categorized visually according to the following criteria: wakefulness was identified by low-voltage fast EEG and high-amplitude EMG; rapid eye movement sleep (REMS) by low-voltage EEG with clear $(6-10 \mathrm{~Hz})$ theta activity and dramatic suppression of EMG with occasional muscle twitches; and NREMS by high-voltage and low-frequency EEG and low-amplitude EMG. Sleep was scored in epochs of $10 \mathrm{sec}$. The behavioral state for each epoch was determined by the predominant state during the epoch. The number of episodes for each behavioral state was calculated by a computer program based on the criterion that the minimal episode length for each state should last at least $30 \mathrm{sec}$.

The FFT data were sorted by a computer program according to the scoring results. The total power in each $5 \mathrm{~Hz}$ frequency band was summed for each $10 \mathrm{sec}$ epoch and then averaged for every $6 \mathrm{hr}$. Results from the $0.5-5 \mathrm{~Hz}$ frequency band are presented; these results are referred to as EEG slow-wave activity. Because the EEG amplitude was subject to the influences of subtle variations of EEG electrode placement, the average total power during NREMS on each saline injection day was normalized to 100 . The relative changes of EEG power from the baseline were calculated for data collected after TNF $\alpha$ or IL-1 $\beta$ treatment.

Sleep and EEG spectrum data were analyzed with two-way ANOVA for repeated measures and followed by a Student-Newman-Keuls (SNK) multiple-comparison test.

\section{RESULTS}

\section{TNFR-KO mice sleep less than strain controls}

Compared with control mice, the TNFR-KO mice had significantly less NREMS $\left[F_{(1,25)}=5.86 ; p<0.05\right]$ and REMS $\left[F_{(1,25)}\right.$ $=10.66 ; p<0.004$ ] (Fig. 1). These decreases in sleep occurred primarily during the light period and in the last few hours during the dark period. There was a significant treatment and time interaction for NREMS $\left[F_{(3,75)}=4.10 ; p<0.01\right]$; SNK multiplecomparison tests indicated that NREMS was decreased significantly in TNFR-KO mice compared with the controls during the first $6 \mathrm{hr}$ of the light period $\left[q_{(4,75)}=5.299 ; p<0.01\right]$. The TNFR-KO mice also had fewer NREMS episodes of shorter duration than the control mice during the period in which they slept less than strain controls, although neither difference was statistically significant. The TNFR-KO mice also had longer REMS to REMS cycles than the controls, although this difference also did not reach statistical significance. The TNFR-KO mice recovered normally from surgery without any signs of infection around the wound. Although not quantified, waking behavior (eating, drinking, and motor activity) and sleep postures of the TNFR-KO mice seemed normal. Similarly, no atypical features in the EEG, EMG, or EEG-FFT transformations were apparent in recordings from either controls or TNFR-KO mice.

\section{TNF55-kDR is involved in TNF $\alpha$-induced sleep}

The effects of TNF $\alpha$ on sleep were examined in the control and TNFR-KO mice. Dose-dependent increases in NREMS were observed in control mice after $\mathrm{TNF} \alpha$ treatment, whereas TNFR-KO mice did not respond to TNF $\alpha$ treatment (Fig. 2; see statistical details in figure legend). The increases of NREMS occurred during the first $9 \mathrm{hr}$ after 1.0 and $3.0 \mu \mathrm{g}$ of TNF $\alpha$ injection; they result from an increase in the number, but not the duration, of NREMS episodes. The number of NREMS episodes occurring in the first $6 \mathrm{hr}$ (postinjection) was almost doubled after $3.0 \mu \mathrm{g}$ of TNF $\alpha\left(62.50 \pm 6.69\right.$ vs $121.17 \pm 13.87 ; F_{(3,15)}=5.26$; $p<0.02$ for treatment and time interaction; $q_{(8,15)}=6.7630 ; p<$ $0.01)$. The high dose $(3.0 \mu \mathrm{g})$ of TNF also decreased the amount of REMS in control mice during the light period; this REMS inhibitory activity of TNF $\alpha$ was absent in the TNFR-KO mice (Fig. 2). The effects of TNF $\alpha$ on EEG slow-wave activity (0.5-5.0 $\mathrm{Hz}$ ) were also determined. The EEG slow-wave activity was not influenced by the low doses of TNF $\alpha(0.3$ and $1.0 \mu \mathrm{g})$, but it was decreased during the first $6 \mathrm{hr}$ after the injection of $3.0 \mu \mathrm{g}$ of $\mathrm{TNF} \alpha$ (Fig. 3; see statistical details in figure legend). TNF $\alpha$ did not have any effects on EEG slow wave activity in TNFR-KO mice (Fig. 3).

\section{IL-1 $\beta$ induces NREMS in TNFR-KO mice}

Although TNFR-KO mice failed to respond to TNF $\alpha$, they displayed a robust increase in NREMS and a decrease in REMS after IL-1 $\beta$ treatment (Fig. 4). IL-1 $\beta$ significantly increased the number $\left[F_{(3,15)}=6.02 ; p<0.01\right.$ for treatment and time interaction; $\left.q_{(6,15)}=6.2303 ; p<0.01\right]$ and the duration $\left[F_{(3,15)}=5.489\right.$; $p<0.01$ for treatment and time interaction; $q_{(8,15)}=5.658 ; p<$ 0.05] of NREMS episodes in TNFR-KO mice during the first $6 \mathrm{hr}$ after injection. IL- $1 \beta$ also significantly decreased the number $\left[F_{(3,15)}=4.47 ; p<0.02\right.$ for treatment and time interaction; $q_{(3,15)}$ $=4.00 ; p<0.05]$ and duration $\left[F_{(3,15)}=6.47 ; p<0.005\right.$ for treatment and time interaction; $\left.q_{(4,15)}=6.5368 ; p<0.01\right]$ of REMS during the same period (data not shown). The EEG slow wave activity was decreased during the first $6 \mathrm{hr}$ after the injection of IL-1 (Fig. 3).

\section{DISCUSSION}

Results presented here extend the list of species, to include mice, in which TNF $\alpha$ and IL- $1 \beta$ are somnogenic. Although abundant evidence suggests that TNF is an important humoral agent involved in sleep regulation, the receptor mechanism for its sleeppromoting effects was heretofore unknown. The TNFR-KO mice fail to respond to $\mathrm{TNF} \alpha$. This was probably not attributable to alterations in physiological sleep in TNFR-KO mice, because NREMS was increased by TNF $\alpha$ in control mice during the first few hours of the dark period, the time during which the control and TNFR-KO mice have similar amounts of sleep. Furthermore, such failure strongly suggests that the sleep-promoting actions of $\mathrm{TNF} \alpha$ are mediated by 55, but not $75 \mathrm{kDa}$, receptors. The 

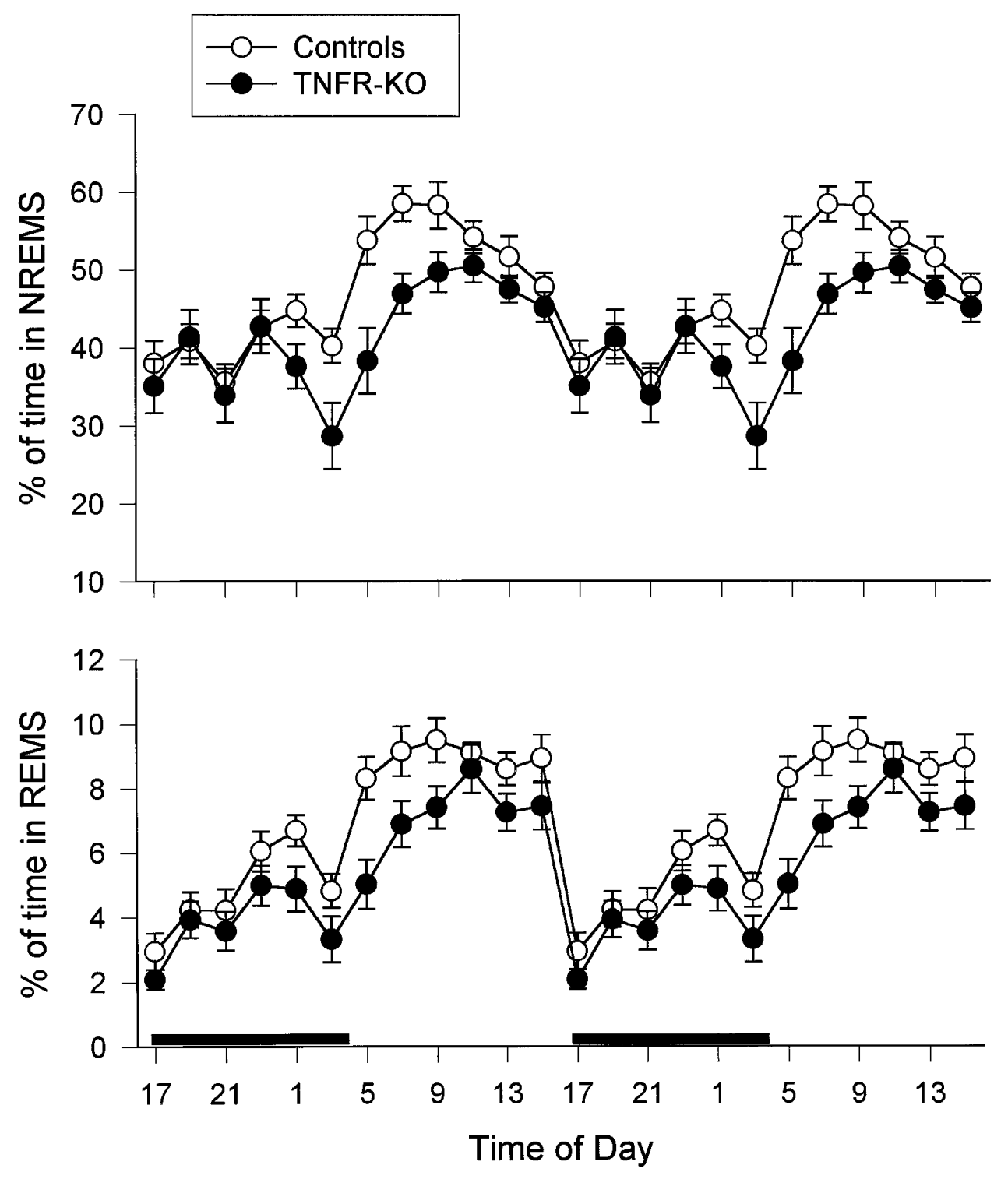

Figure 1. Double plot of $24 \mathrm{hr}$ sleep patterns in control $(n=13)$ and TNFR-KO $(n=14)$ mice. The amounts of NREMS (top) and REMS (bottom) are expressed as percent of time in each state. Each data point is a $2 \mathrm{hr}$ average. The vertical bars indicate SE. The black bar in the bottom panel indicates the dark period.

importance of this finding is twofold. First, localization of TNF55 $\mathrm{kDa}$ receptors in the brain may provide information about the sleep-promoting sites of TNF $\alpha$. Second, the $55 \mathrm{kDa}$ and $75 \mathrm{kDa}$ receptors mediate distinct actions, probably because of the differences in their intracellular domains. Knowledge of the TNF55 $\mathrm{kDa}$ receptor-mediated actions may provide important clues for the understanding of the intracellular mechanisms of sleep regulation.

The finding that the TNFR-KO mice have less NREMS than their strain controls (44.9 vs $55.9 \%$ ) provides further evidence that endogenous TNF is involved in physiological sleep regulation. The B6 $\times 129-\mathrm{F} 2$ mice were chosen as a control strain, because this is the background on which the KO strain was developed. However, the genetic mix produced when selecting for a $\mathrm{KO}$ is different from a random mix produced by crossing two lines (Gerlai, 1996). Results, therefore, need to be interpreted with caution. Unfortunately, there is no ideal control strain; nevertheless, comparisons to a variety of strains of mice support the hypothesis that the TNFR-KO mice have a deficit in NREMS during daylight hours. Thus, other strains of mice recorded from in our laboratory [Swiss-Webster (Fang et al., 1996a), B6D2F1
(Zhang et al., 1996) and an IL-1 receptor KO strain (Fang et al., 1996b)] all have more NREMS during daylight hours than the TNFR-KO strain (Fig. 5). Furthermore, the TNFR-KO mice have less NREMS than C57BL/6 and BALB/c mice (Roussal et al., 1984) (Fig. 5). The observation that TNFR-KO mice slept less than the controls primarily during the light period is consistent with the findings that the levels of TNF $\alpha$ mRNA (Bredow et al., 1996) and TNF $\alpha$ (Floyd et al., 1996) in the hypothalamus and hippocampus are greater during the light period than during the dark period in rats. Rats, like mice, also spend most of their time sleeping during daylight hours. Nevertheless, the results of the current experiment cannot exclude the possibility that the reduced sleep in TNFR-KO mice might be attributable to other abnormalities in these mice that manifest themselves during daylight hours.

The decrease of REMS in TNFR-KO mice was not expected, because REMS was not changed after low doses of TNF $\alpha$ and was actually inhibited after high doses of $\mathrm{TNF} \alpha$ in controls. Administration of high doses of exogenous $\mathrm{TNF} \alpha$ also inhibits REMS in rabbits (Kapas et al., 1992), whereas inhibition of endogenous TNF using a soluble TNF receptor fragment inhibits 
B6x129-F2
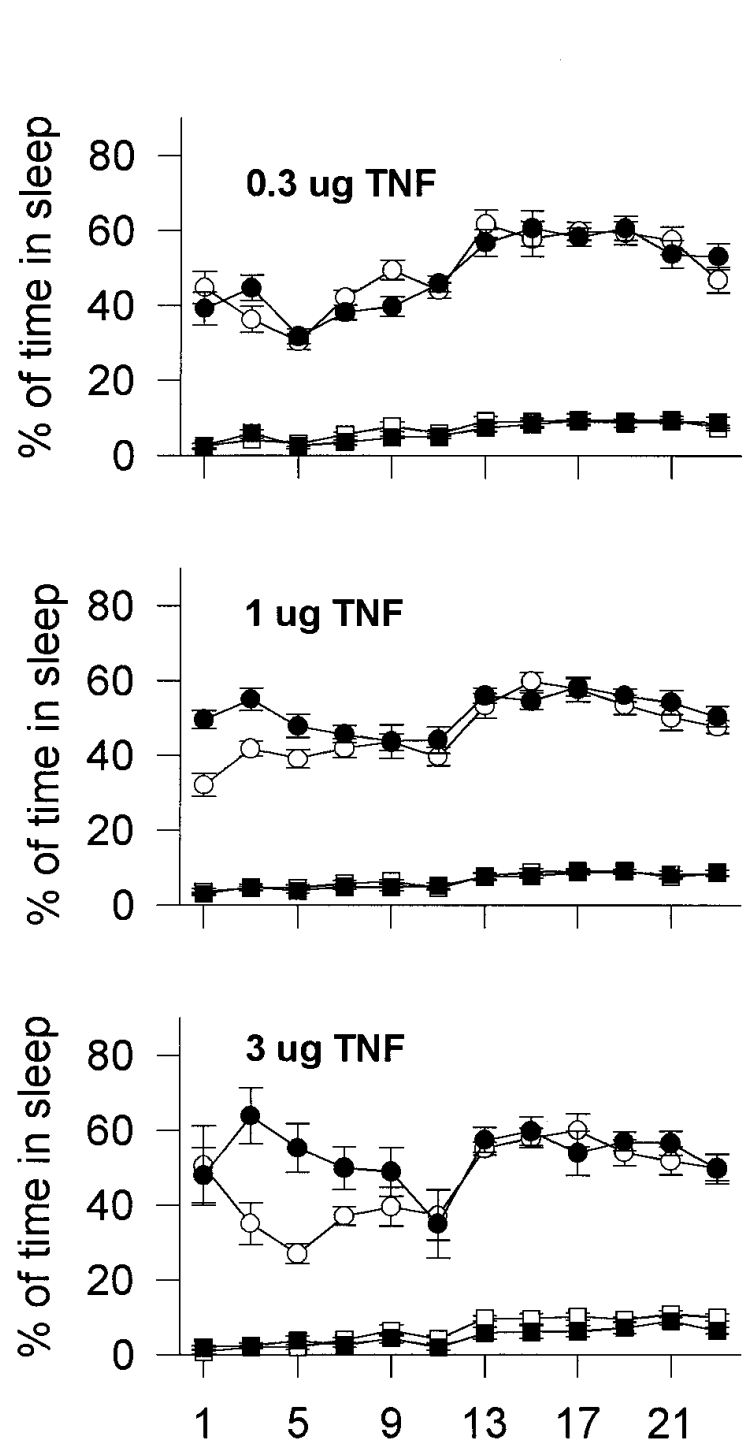

Hours after injection
TNFR knockout
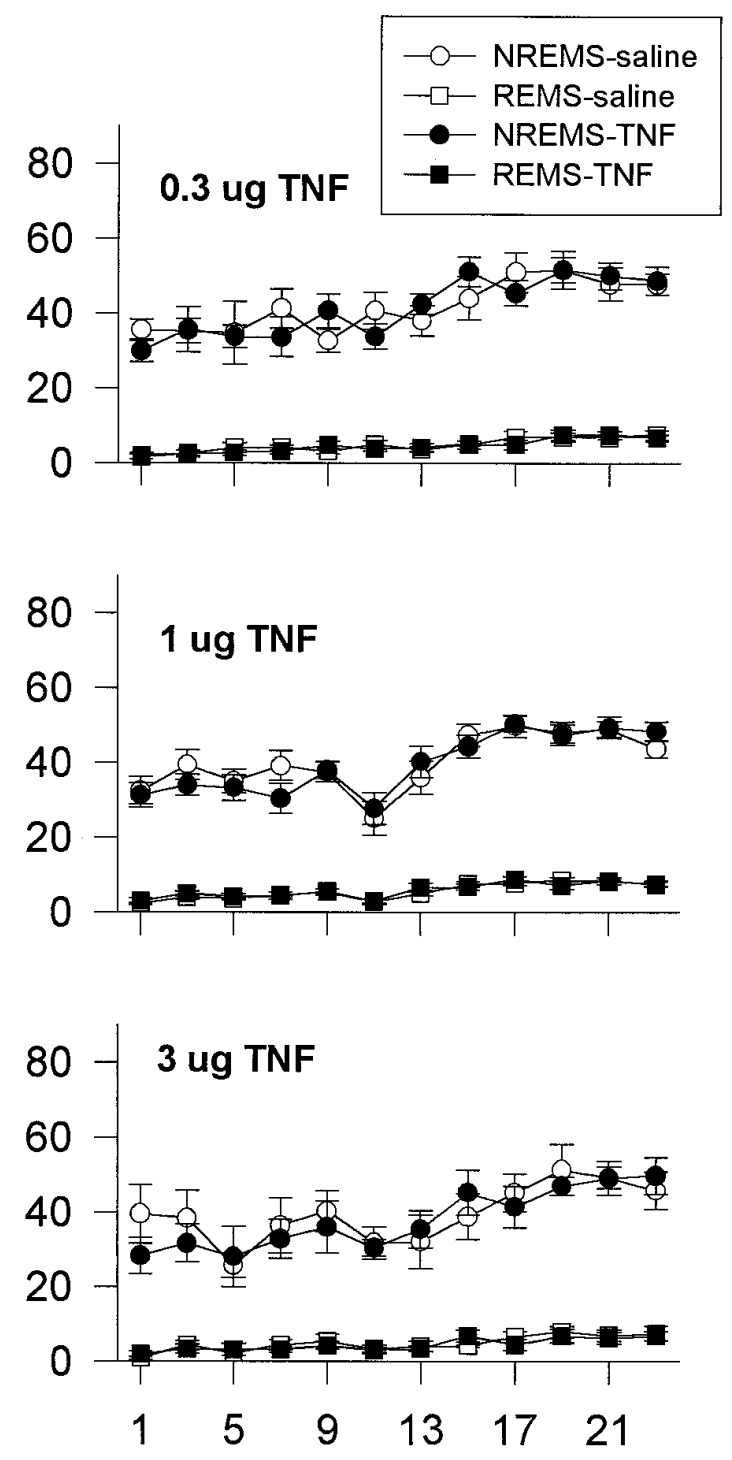

Hours after injection

Figure 2. Effects of various doses of mouse recombinant TNF $\alpha$ in control and TNFR-KO mice. Control mice (left) had a significant increase in NREMS after $1.0 \mu \mathrm{g}\left[F_{(1.12)}=12.01 ; p<0.005\right]$ and $3.0 \mu \mathrm{g}\left[F_{(1.5)}=7.34 ; p<0.05\right.$ for interaction; $q_{(1.5)}=4.932$ for hours $\left.1-12\right]$ of TNF $\alpha$ and a significant decrease in REMS after $3.0 \mu \mathrm{g}$ of TNF $\alpha\left[F_{(1,5)}=26.37 ; p<0.004\right.$ for interaction; $q_{(2,5)}=4.357 ; p<0.05$ for hours $\left.13-24\right]$. TNFR-KO mice (right) did not respond to TNF $\alpha$ treatments.

NREMS but enhances REMS after sleep deprivation in rabbits (Takahashi et al., 1996c). It is not clear whether the lower amount of REMS in TNFR-KO mice is an indirect result of deficits in NREMS thereby limiting the normal access route to REMS via NREMS or is attributable to the lack of direct TNF actions on REMS-promoting mechanisms.

EEG slow-wave amplitudes decreased after $\mathrm{TNF} \alpha$ (in control mice) and IL-1 $\beta$ (in TNFR-KO mice) treatments during the first $6 \mathrm{hr}$, after injection. In rats (Tobler et al., 1984; Opp et al., 1991) and rabbits (Krueger et al., 1984) these cytokines induce increases in EEG slow-wave activity after intracerebroventricular injections. Furthermore, during NREMS after sleep deprivation EEG slow-wave activity increases (Pappenheimer et al., 1975); this latter result is interpreted to indicate that EEG slow-wave activity is a measure of sleep intensity (Borbély and Tobler, 1989). Current results could be attributable to the route of administration. For example, we found recently that intraperitoneal injections of IL- $1 \beta$ into rats also decreased EEG slow-wave activity, although it did induce increases in NREMS duration (Hansen and Krueger, unpublished observation). Species differences may also be important. For example, although administration of exogenous $\mathrm{TNF} \alpha$ induces fever in rats and rabbits, it actually decreases body temperature in mice (Kozak et al., 1995). Because EEG amplitudes increase with ambient temperature and brain temperature, it is possible that $\mathrm{TNF} \alpha$ may suppress EEG amplitudes by decreasing body temperature. EEG slow-wave activity in mice is greater during the dark period, when mice spend most of their time awake, than in the light period when mice 


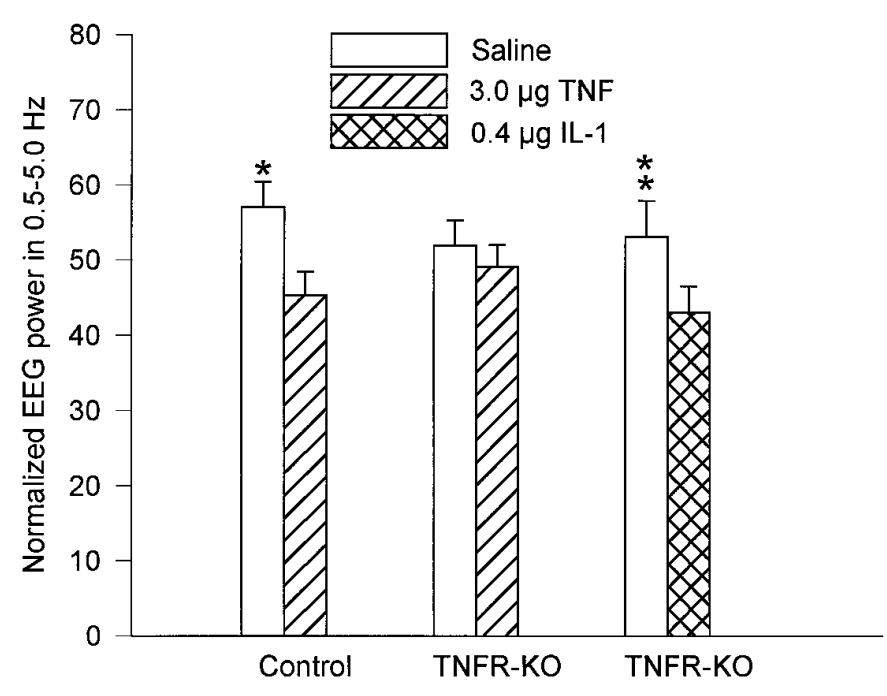

Figure 3. Effects of TNF $\alpha$ and IL-1 $\beta$ on EEG slow-wave activity (SWA). The average of total power $(0.5-35.0 \mathrm{~Hz})$ during NREMS on saline injection day was normalized to 100 . ${ }^{*} \mathrm{TNF} \alpha$ significantly decreased EEG SWA in control mice but not in TNFR-KO mice during the first $6 \mathrm{hr}$ after injection $\left[F_{(3,15)}=10.559 ; p=0.0006 ; q_{(8,15)}=7.574 ; p<0.01\right]$. **IL-1 $\beta$ significantly decreased EEG SWA $\left[F_{(3,15)}=6.68 ; p<0.005\right.$ for treatment and time interaction; $\left.q_{(4,15)}=6.417 ; p<0.01\right]$.
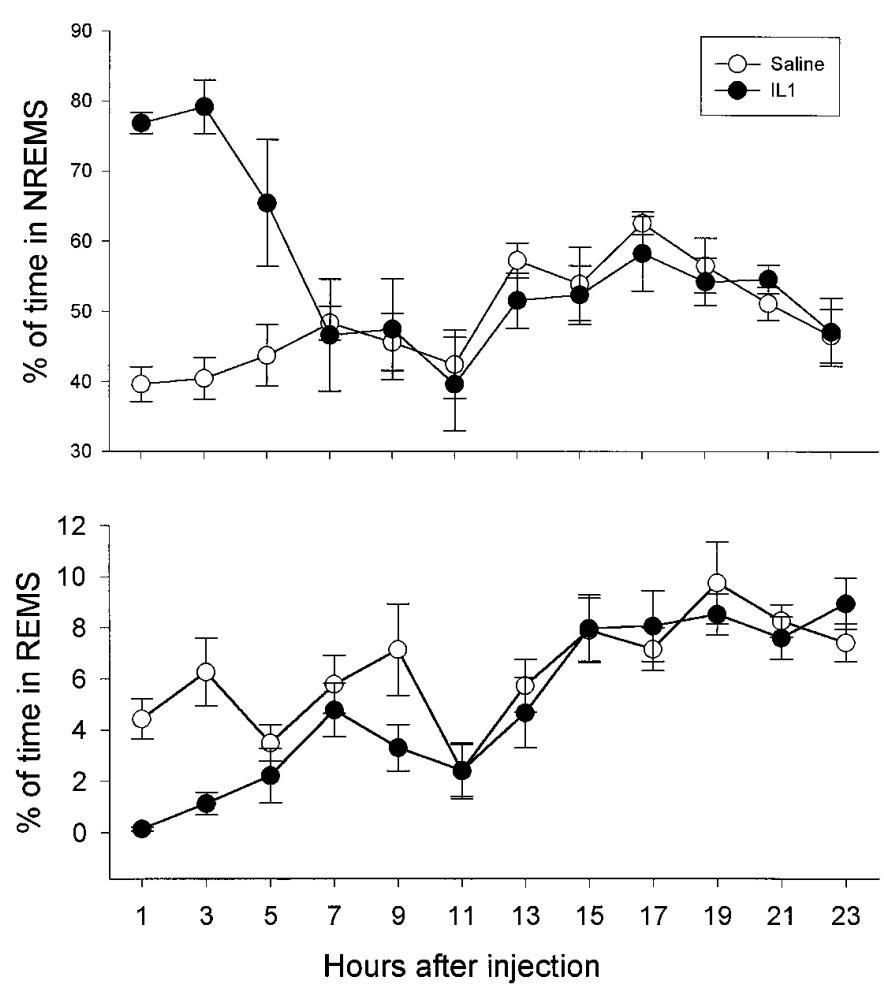

Figure 4. Effects of $0.4 \mu \mathrm{g}$ IL-1 on sleep in TNFR-KO mice. IL-1 significantly increased NREMS $\left[F_{(1,5)}=11.13 ; p<0.025\right]$ and decreased $\operatorname{REMS}\left[F_{(1,5)}=8.31 ; p<0.05\right.$ for treatment and time interaction; $q_{(2,5)}=$ 4.188; $p<0.05$ for nighttime].

spend most of their time asleep (Tobler et al., 1996). Furthermore, cytokines can have divergent effects on NREMS duration and EEG slow-wave activity depending on dose and time of day. In rats, high doses of IL- $1 \beta$ reduce EEG slow-wave activity during the dark period and increase it during the light period,

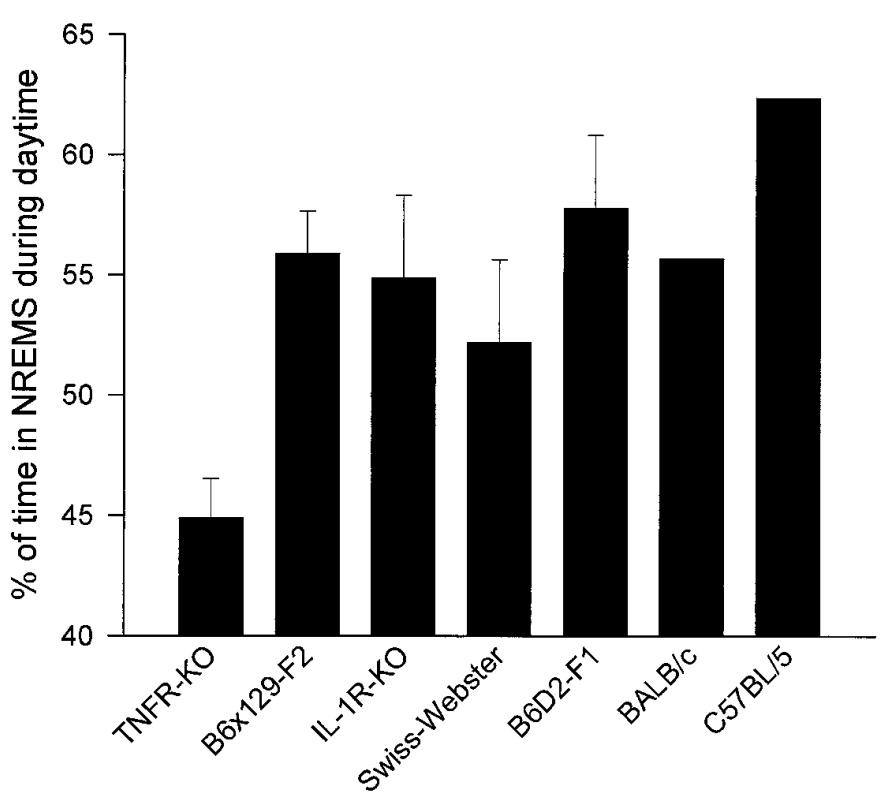

\section{Strains of mice}

Figure 5. Percent of time spent in NREMS in seven different strains of mice. TNFR-KO mice have less NREMS than six other strains during daylight hours. Sleep data for TNFR-KO, B6 × 129-F2, IL-1 type I receptor KO $(I L-1 R-K O)$, Swiss-Webster, and $\mathrm{B} 6 \mathrm{D} 2-\mathrm{F} 1$ mice are from our laboratory. Data for C57BL/6 and BALB/c mice were from another laboratory (Roussel et al., 1984), and the SE were not available.

whereas low doses of IL- $1 \beta$ increase EEG slow-wave activity during both dark and light periods (Opp et al., 1991). Additional data also indicate that duration of NREMS and EEG slow-wave amplitudes are separable. Lesions of the hypothalamic preoptic area reduce NREMS duration and EEG slow-wave amplitude (Shoham et al., 1987b); after $8 \mathrm{~d}$ of recovery NREMS duration recovers, but EEG slow-wave activity remains depressed. Similar results were obtained after immunotoxin lesions of basal forebrain cholinergic neurons (Kapás et al., 1996). Rats fed a cafeteria diet increase duration of NREMS but decrease EEG slowwave activity (M. Hansen, L. Kapás, and J. M. Krueger, unpublished observation). Finally, in rats, restricting food availability to daytime hours reverses the circadian rhythm of NREMS duration but does not affect the circadian rhythm of EEG slow-wave activity (Roky et al., 1995).

Sleep is regulated by multiple substances, and there are complex interactions among these humoral agents (Krueger et al., 1994). IL- $1 \beta$ and TNF $\alpha$ are two of the best characterized sleepregulatory substances. IL $-1 \beta$ and $\mathrm{TNF} \alpha$ induce the production of each other (Bachwich et al., 1986; Dinarello et al., 1986; Philip and Epstein, 1986). Inhibition of IL-1 $\beta$ attenuates TNF $\alpha$-induced sleep, whereas inhibition of TNF $\alpha$ attenuates IL- $1 \beta$-induced sleep (Takahashi et al., 1996a). However, it is not clear whether $\mathrm{TNF} \alpha$ is necessary for the sleep-promoting effects of IL- $1 \beta$ and vice versa. The result that recombinant murine IL- $1 \beta$ induces robust increases in NREMS in TNFR-KO mice indicates that the TNF $55 \mathrm{kDa}$ receptor is not necessary for the sleep-promoting effects of IL-1 $\beta$. It is also unlikely that the actions of TNF via its $75 \mathrm{kDa}$ receptor are involved in IL- $1 \beta$-induced sleep, because the present results indicate that the TNF $75 \mathrm{kDa}$ receptor is not involved in sleep regulation. Therefore, IL- $1 \beta$ is capable of inducing NREMS independently of TNF. We have also shown 
recently that IL-1 type I receptor KO mice do not have sleep responses to IL- $1 \beta$ but exhibit increased NREMS after TNF $\alpha$ (Fang et al., 1996b). Therefore, the IL-1 type I receptor is not necessary for the sleep-promoting effect of TNF $\alpha$. Another related question is whether one sleep regulatory substance can compensate for the deficit of another. The result that TNFR-KO mice have less sleep than controls indicates that the deficit in TNF function is not, or at least not completely, developmentally compensated for by other sleep-promoting substances. In addition, we observed that IL-1 type I receptor KO mice have less NREMS compared with strain control mice during the dark period (Fang et al., 1996c), indicating that a deficit in IL-1 function is also not developmentally compensated. The IL-1 type I receptor $\mathrm{KO}$ mice also had significantly more REMS during the light period. The results from these two types of KO mice suggest that IL-1 and TNF promote sleep during different times of the day. Alternatively, IL- $1 \beta$ may contribute to physiological sleep both during light and dark periods, but the developmental compensation for the loss of TNF $\alpha$ and IL- $1 \beta$ is different. This latter interpretation is supported by the observation that temporary inhibition of IL-1 with anti-IL-1 antibodies inhibits spontaneous sleep during the light period in rats (Opp and Krueger, 1994). In conclusion, current results strongly support the notion that TNF $\alpha$ is involved in sleep regulation.

\section{REFERENCES}

Bachwich PR, Chensue SW, Larric JW, Kunkel SL (1986) Tumor necrosis factor stimulates interleukin-1 and prostaglandin $\mathrm{E}_{2}$ production in resting macrophages. Biochem Biophys Res Commun 136:94-101.

Borbély AA, Tobler I (1989) Endogenous sleep-promoting substances and sleep regulation. Physiol Rev 69:605-670.

Breder CD, Tsujimoto M, Terano Y, Scott DW, Saper CB (1993) Distribution and characterization of tumor necrosis factor- $\alpha$-like immunoreactivity in the murine central nervous system. J Comp Neurol 337:543-567.

Bredow S, Obál Jr F, Guha-Thakurta N, Taishi P, Krueger JM (1996) Hypothalamic GHRH mRNA and TNF $\alpha$ mRNA levels are higher during the day than night. Soc Neurosci Abstr 22:146.

Darko DF, Miller JC, Gallen C, White W, Koziol J, Brown SJ, Hayduk R, Atkinson JH, Assmus J, Munnell DT, Naitoh P, McCutchen JA, Mitler MM (1995) Sleep electroencephalogram delta frequency amplitude, night plasma levels of tumor necrosis factor $\alpha$ and human immunodeficiency virus infection. Proc Natl Acad Sci USA 92:12080-12084.

Dinarello CA, Cannon JG, Wolff SM, Bernheim HA, Beutler B, Cerami A, Figari IS, Palladino Jr MA, O'Connor JV (1986) Tumor necrosis factor (cachectin) is an endogenous pyrogen and induces production of interleukin 1. J Exp Med 163:1433-1450.

Fang J, Tooley D, Gatewood C, Renegar KB, Majde JA, Krueger JM (1996a) Differential effects of total and upper airway influenza viral infection on sleep in mice. Sleep 19:337-342.

Fang J, Renegar KB, Kapás L, Wang Y, Krueger JM (1996b) The IL-1 type I receptor and the TNF $55 \mathrm{kDa}$ receptor are involved in sleep regulation. J Sleep Res [Suppl] 5:62.

Fang J, Wang Y, Krueger JM (1996c) The TNF $55 \mathrm{kDa}$ receptor and the IL-1 type receptor are involved in physiological sleep regulation. Soc Neurosci Abstr 22:147.

Floyd RA, Krueger JM (1997) Diurnal variations of TNFa in the brain. NeuroReport, in press.

Gerlai R (1996) Gene targeting in neuroscience: the systemic approach. Trends Neurosci 19:188-189.

Hohagen F, Timmer J, Weyerbrock A, Fritsch-Montero R, Ganter U, Krieger S, Berger M, Bauer J (1993) Cytokine production during sleep and wakefulness and its relationship to cortisol in healthy humans. Neuropsychobiology 28:9-16.

Hohmann H-P, Remy R, Brockhaus M, van Loon APGM (1989) Two different cell types have different major receptors for human tumor necrosis factor (TNF $\alpha$ ). J Biol Chem 264:14927-14934.
Hohmann H-P, Brockhaus M, Bauerle PA, Remy R, Kolbeck R, van Loon APGM (1990) Expression of the type A and B tumor necrosis factor (TNF) receptor is independently regulated, and both receptors mediate activation of the transcription factor NF-kB. J Biol Chem 265:22409-22417.

Hunt JS, Chen HL, Hu XL, Chen TY, Morrison DC (1992) Tumor necrosis factor-alpha gene expression in the tissue of normal mice. Cytokine 4:340-346.

Kapás L, Hong L, Cady AB, Opp MR, Postlethwaite AE, Seyer JM, Krueger JM (1992) Somnogenic, pyrogenic, and anorectic activities of tumor necrosis factor- $\alpha$ and TNF- $\alpha$ fragments. Am J Physiol 263:R708-R715.

Kapás L, Obál Jr F, Book AA, Schweitzer JB, Wiley RG, Krueger JM (1996) The effects of immunolesions of nerve growth factor-receptive neurons by 192 IgG-saporin on sleep. Brain Res 712:53-59.

Kozak W, Conn CA, Klir JJ, Wong GH, Kluger MJ (1995) Soluble receptor and antiserum against TNF enhance lipopolysaccharide fever in mice. Am J Physiol 269:R23-R29.

Krueger JM, Walter J, Dinarello CA, Wolff SM, Chedid L (1984) Sleeppromoting effects of endogenous pyrogen (interleukin-1). Am J Physiol 246:R994-R999.

Krueger JM, Toth LA, Floyd R, Fang J, Kapás L, Obál Jr F (1994) Sleep, microbes and cytokines. Neuroimmunomodulation 1:100-109.

Lieberman AP, Pitha PM, Shin HS, Shin ML (1989) Production of tumor necrosis factor and other cytokines by astrocytes stimulated with lipopolysaccharide or a neutrotopic virus. Proc Natl Acad Sci USA 86:6348-6352.

Nistico G, DeSarro G, Rotiroti D (1992) Behavioral and electrocortical spectrum poer changes of interleukins and tumor necrosis factor after microinjection into different areas of the brain. In: Sleep, hormones and immunological system (Smirne et al., eds), pp 11-22. Milan: Masson.

Opp MR, Krueger JM (1994) Anti-interleukin-1 $\beta$ reduces sleep and sleep rebound after sleep deprivation in rats. Am J Physiol 266:R688-R695.

Opp MR, Obál Jr F, Krueger JM (1991) Interleukin-1 alters rat sleep: temporal and dose-related effects. Am J Physiol 260:R52-R58.

Pappenheimer JR, Koski G, Fencyl V, Karnovsky ML, Krueger JM (1975) Extractions of sleep-promoting factors from cerebrospinal fluid and from brains of sleep-deprived animals. J Neurophysiol 38:1299-1311.

Philip R, Epstein LB (1986) Tumor necrosis factor as immunomodulator and mediator of monocyte cytotoxicity induced by itself, gammainterferon and interleukin-1. Nature 323:86-89.

Puccioni-Sohler M, Rieckmann P, Kitze B, Lange P, Albrecht M, Flegenhauer K (1995) A soluble form of tumor necrosis factor receptor in cerebrospinal fluid and serum of HTLV-1-associated myelopathy and other neurological diseases. Neurology 242:239-242.

Roky R, Kapás L, Fang J, Krueger JM (1995) Restricted feeding to the light period affects the circadian rhythm of sleep and brain temperature in the rat. Sleep Res 24A:540.

Rothe J, Lesslauer W, Lötscher H, Lang Y, Koebel R, Köntgen F, Althage A, Zinkernagel R, Steinmetz M, Bluethmann H (1993) Mice lacking the tumor necrosis factor 1 are resistant to TNF-mediated toxicity but highly susceptible to infection by Listeria monocytogenes. Nature 364:798-802.

Roussel B, Turrillot P, Kitahama K (1984) Effects of ambient temperature on the sleep-waking cycle in two strains of mice. Brain Res 294:67-73.

Schall TJ, Lewis M, Koller KJ, Lee A, Rice GC, Wong GHW, Gatanaga T, Granger GA, Lentz R, Raab H, Kohr WJ, Goeddel DV (1990) Molecular cloning and expression of a receptor for human tumor necrosis factor. Cell 61:361-370.

Schutze S, Machleidt T, Krönke M (1994) The role of diacylglycerol and ceramide in tumor necrosis factor and interleukin-1 signal transduction. J Leukoc Biol 56:533-541.

Shoham S, Davenne D, Cady AB, Dinarello CA, Krueger JM (1987a) Recombinant tumor necrosis factor and interleukin-1 enhances slowwave sleep. Am J Physiol 253:R142-R149.

Shoham S, Blatteis CM, Krueger JM (1987b) Effects of preoptic area lesions on muramyl dipeptide-induced sleep and fever. Brain Res 476:396-399.

Takahashi S, Kapás L, Fang J, Krueger JM (1995a) An anti-tumor necrosis factor antibody suppresses sleep in rats and rabbits. Brain Res 690:241-244. 
Takahashi S, Tooley DD, Kapás L, Fang J, Seyer JM, Krueger JM (1995b) Inhibition of tumor necrosis factor in the brain suppresses rabbit sleep. Pflügers Arch 431:155-160.

Takahashi S, Kapás L, Fang J, Seyer JM, Krueger JM (1996a) Somnogenic relationships between interleukin-1 and tumor necrosis factor. Sleep Res 25:31.

Takahashi S, Kapás L, Krueger JM (1996b) A tumor necrosis factor (TNF) receptor fragment attenuates $\mathrm{TNF} \alpha$ and muramyl dipeptideinduced sleep and fever in rabbits. J Sleep Res 5:106-114.

Takahashi S, Kapás L, Seyer JM, Wang Y, Krueger, JM (1996c) Inhibition of tumor necrosis factor attenuates physiological sleep in rabbits. NeuroReport 7:642-646.

Takahashi S, Kapás L, Seyer JM, Wang Y, Krueger JM (1997) Inhibition of tumor necrosis factor prevents warming-induced sleep responses in rabbits. Am J Physiol, in press.

Tchelingerian J, Vignais LL, Jacque C (1994) TNF alpha gene expression is induced in neurons after a hippocampal lesion. NeuroReport 5:585-588.
Tobler I, Borbély AA, Schwyzer M, Fontana A (1984) Interleukin-1 derived from astrocytes enhances slow-wave activity in sleep EEG of the rat. Eur J Pharmacol 104:191-192.

Tobler I, Gaus SE, Deboer T, Achermann P, Fischer M, Rülicker T, Moser M, Oesch B, McBride PA, Manson JC (1996) Altered circadian activity rhythms and sleep in mice devoid of prion protein. Nature 380:639-642.

Uthgenannt D, Schoolmann D, Pietrowsky R, Fehm HL, Born J (1994) Effects of sleep on production of cytokines in humans. Psychosom Med 57:97-104.

Vilcek J, Lee TH (1991) Tumor necrosis factor. J Biol Chem 266:7313-7316.

Yamasu K, Shimada Y, Sakaizumi M, Soma G, Mizuno D (1992) Activation of the systemic production of tumor necrosis factor after exposure to acute stress. Eur Cytokine Netw 3:391-398.

Zhang J, Obál Jr F, Fang J, Collins BJ, Krueger JM (1996) Sleep is suppressed in transgenic mice with a deficiency in the somatotropic system. Neurosci Lett 220:97-100. 